\title{
Monitoring Urban Spatial Growth in Harare Metropolitan Province, Zimbabwe
}

\author{
Courage Kamusoko ${ }^{1}$, Jonah Gamba ${ }^{2}$, Hitomi Murakami ${ }^{3}$ \\ ${ }^{1}$ Asia Air Survey (AAS) Co., Ltd, Kanagawa, Japan \\ ${ }^{2}$ TOPS Systems Corp., Tsukuba, Japan \\ ${ }^{3}$ Department of Computer and Information Science, Faculty of Science and Technology, Seikei University, Tokyo, Japan \\ Email: *cou.kamusoko@ajiko.co.jp
}

Received October 21, 2013; revised November 21, 2013; accepted November 27, 2013

Copyright (C) 2013 Courage Kamusoko et al. This is an open access article distributed under the Creative Commons Attribution License, which permits unrestricted use, distribution, and reproduction in any medium, provided the original work is properly cited.

\begin{abstract}
Taking Harare metropolitan province in Zimbabwe as an example, we classified Landsat imagery (1984, 2002, 2008 and 2013) by using support vector machines (SVMs) and analyzed built-up and non-built-up changes. The overall classification accuracy for the four dates ranged from $89 \%$ to $95 \%$, while the overall kappa varied from $86 \%$ to $93 \%$. The results demonstrate that SVMs provide a cost-effective technique for mapping urban land use/cover by using mediumresolution satellite images such as Landsat. Based on land use/cover maps for 1984, 2002, 2008 and 2013, along with change analyses, built-up areas increased from $12.6 \%$ to $36.3 \%$ of the total land area, while non-built-up cover decreased from $87.3 \%$ to $63.4 \%$ between 1984 and 2013 . The results revealed an urban growth process characterized by infill, extension and leapfrog developments. Given the dearth of spatial urban growth information in Harare metropolitan province, the land use/cover maps are valuable products that provide a synoptic view of built-up and non-built-up areas. Therefore, the land use/cover change maps could potentially assist decision-makers with up-to-date built-up and non-built-up information in order to guide strategic implementation of sustainable urban land use planning in Harare metropolitan province.
\end{abstract}

Keywords: Harare Metropolitan Province; Zimbabwe; Urbanization; Support Vector Machines (SVMs); Urban Sprawl

\section{Introduction}

Globally, the rapid increase in urbanization poses a number of challenges to urban planners and policy makers [1,2]. It is estimated that more than five billion people will be living in urban areas by 2030 , of which $80 \%$ of these will be inhabitants of urban areas in developing countries [3-5]. While Sub-Saharan Africa is the least urbanized region, its urban population is increasing rapidly than other regions of the world [6-8]. To date, most urban areas in Sub-Saharan Africa are confronted with problems such as rapid population growth, increasing rural-urban migration, proliferation of informal settlements and epidemics as well as environmental degradation $[9,10]$. In order to formulate sustainable urban development strategies in Sub-Saharan Africa, timely and up-to-date land use/cover information is required [11]. Although the need for accurate land use/cover information has long been recognized as a fundamental input for

${ }^{*}$ Corresponding author. sustainable urban planning, efforts to produce or update existing land use/cover maps have been hampered by high cost of conducting conventional land use surveys as well as acquiring and processing aerial photographs [12]. However, the past decades have witnessed an increase in the use of medium-resolution satellite data for mapping urban land use/cover [2,13-15] since some of the data are relatively cheap or freely available.

Although medium-resolution satellite data have highlighted significant insights into urban land use/cover changes, previous studies revealed misclassification problems when commonly-used per-pixel maximum likelihood supervised and unsupervised algorithms are used for image classification $[16,17]$. This is mainly attributed to the heterogeneous nature of urban landscapes, where the juxtaposition of continuous and discrete elements as well as the existence of relatively small spatial size of surficial materials leads to spectral confusion and subpixel mixing [18-21]. Nonetheless, the remote sensing community has worked tirelessly to develop advanced 
classification techniques given the rapid advances in computer and satellite technology. Examples of advanced classification techniques include combining satellite images with ancillary data [22], incorporating structural and textural information [23,24], expert systems [21], hybrid methods that incorporate soft and hard classifications [16], use of normalized difference built-up index $[25,26]$, neural networks [27], object-based classifications [15], and support vector machines [28-30].

While significant improvements in urban land use/ cover classification have been noted, most studies using advanced classification techniques have been conducted in developed countries, which are characterized by a highly developed urban built-up environment and wellplanned urban land use system. However, more studies are needed to reduce uncertainties in land use/cover classification [17,31], particularly in developing countries. For instance, some urban areas are generally characterized by unplanned urban expansion coupled with subsistence urban agriculture systems [32]. This poses numerous methodological challenges for urban land use/cover classifications, particularly for Harare metropolitan province, which is characterized by complex and contrasting spatial and socioeconomic development patterns. For example, similar spectral responses between built-up areas on the one hand, and bare vacant plots and agriculture areas on the other hand, have been observed to cause classification errors [33]. Nonetheless, recent studies have demonstrated the effectiveness of support vector machines (SVMs) for classifying land use/cover $[30,34]$. This is because SVMs are highly adaptable, non-parametric, and they require few training areas for classification $[30,35]$.

The objective of this study was to map and analyze built-up and non-built-up cover in Harare metropolitan province. We used Landsat data for 1984, 2002, 2008 and 2013 to classify built-up and non-built-up cover, and a post-classification change detection technique to analyze land use/cover changes. This study area was selected because very little quantitative information exists on how much land has been converted to built-up areas despite the rapid population expansion in Harare metropolitan province. In addition, the processes and problems of urban growth in Harare are similar to those in other southern African metropolitan areas, particularly in former British colonies since they share common historical origins and planning principles [36].

\section{Study Area}

Harare metropolitan province comprises four districts namely, Harare Urban, Harare Rural, Chitungwiza and Epworth (Figure 1). The metropolitan province extends between approximately $17^{\circ} 40^{\prime}$ and $18^{\circ} 00^{\prime}$ south, and between $30^{\circ} 55^{\prime}$ and $31^{\circ} 15^{\prime}$ east, encompassing an area of

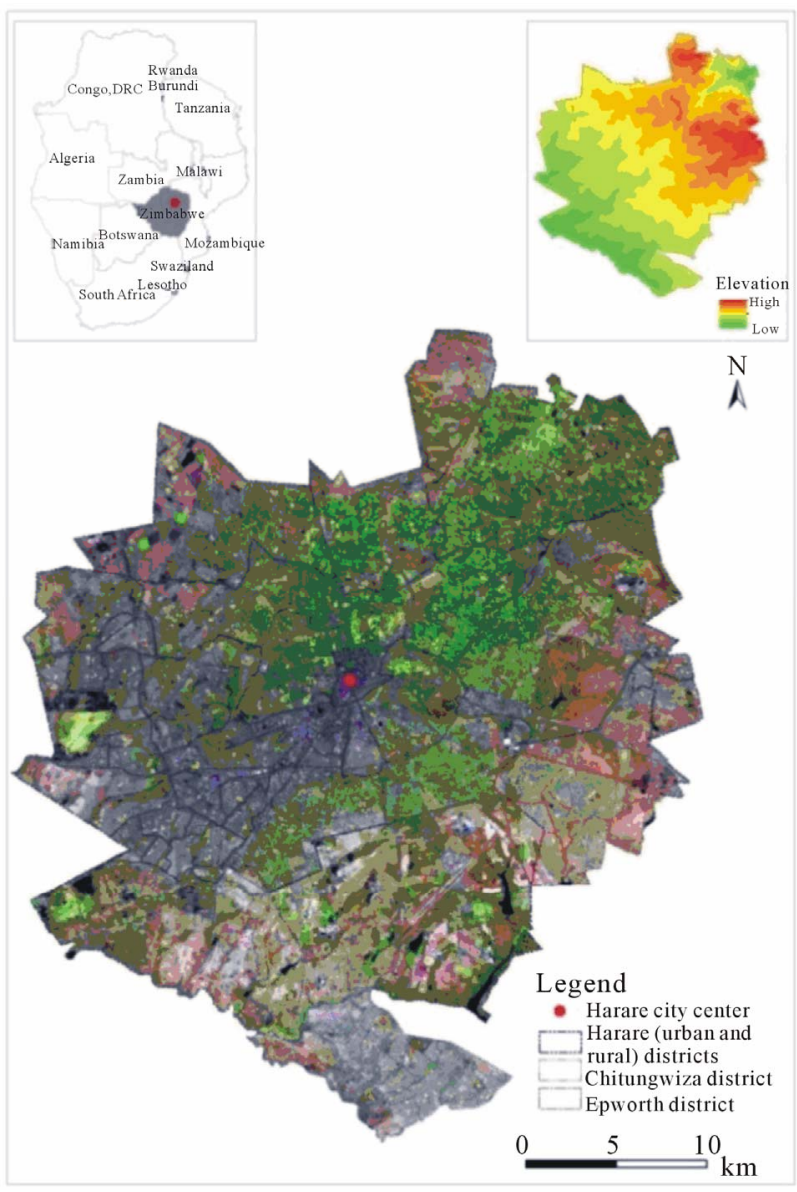

Figure 1. Location of the study area. District boundaries for Harare (Urban and Rural), Chitungwiza and Epworth are overlaid on Landsat 8 image in bands $5,4,3$ (R,G,B) acquired on 6 June 2013.

about $942 \mathrm{~km}^{2}$. The average altitude is approximately $1500 \mathrm{~m}$ above sea level. The study area is characterized by a warm, wet season from November to April; a cool, dry season from May to August; and a hot, dry season in October. Daily temperatures range from about $7^{\circ} \mathrm{C}$ to $20^{\circ} \mathrm{C}$ in July (coldest month), and from $13^{\circ} \mathrm{C}$ to $28^{\circ} \mathrm{C}$ in October (hottest month). The study area receives a mean annual rainfall ranging from $470 \mathrm{~mm}$ to $1350 \mathrm{~mm}$ between November and March. Vegetation varies from grasslands to open Miombo woodlands dominated by Brachystegia spiciformis trees as well as some introduced tree species such as Jacaranda. The metropolitan province is dominated by a complex of: gabbro and dolerite to the north; an intrusion of metagreywacke and phylite in the centre; and granites to the east, and southwest. The underlying geology has a marked influence on the soils in the study area, which are mostly fersialitic and paraferrallitic soils [37]. Poorly drained areas occur in widespread vleis, which are mainly depressions with soils that are waterlogged during the rainy season.

Harare Urban district incorporates the City of Harare, 
which is the capital and largest city in Zimbabwe. The spatial structure of the City of Harare is characterized by a radial road network with the central business district (CBD) at its core, and the industrial areas to the east and south [33]. To the north and northeast are the spacious low density residential areas on plot sizes of about 1000 $\mathrm{m}^{2}$ or more, while to the extreme east, south, southwest and west are the high density residential areas on plot sizes of about $300 \mathrm{~m}^{2}$ [33]. In addition, some medium density residential measuring between 800 and $1000 \mathrm{~m}^{2}$ are found in the southern part of the study area. Pre-independence City of Harare was divided along racial lines, whereas post-independent was divided along socioeconomic divisions. Services and amenities in lowincome high density residential areas, where high population densities are located are poor and inadequate [36,38]. The population in Harare Urban district has been increasing at a fast rate since independence in 1980, when migration controls were removed [38,39]. The population in Harare Urban district increased from approximately 642,191 in 1982 to $1,435,784$ in 2012, while the population in Harare Rural district increased from 16,173 to 23,023 over the same period $[10,40,41]$.

Chitungwiza city, which lies approximately $25 \mathrm{~km}$ south of the city of Harare, was developed out of St Mary's (formerly a settlement designated for missionary services and churches) and Seke townships in the early 1970s. The city was developed by the colonial government in order to locate residential areas for Africans far from the City of Harare. The population of Chitungwiza city expanded exponentially from approximately 15,000 in 1969 to 354,472 in 2012 [36,41]. Population expansion was mainly driven by people who migrated from the rural areas during the liberation struggle in the 1970s [9]. While Chitungwiza has commercial and industrial enterprises, most of its residents work in the City of Harare. Epworth, which is located in the south-east of the City of Harare is an unplanned and informal urban settlement that was formed by war refugees during the liberation struggle in the 1970s [10]. The population of Epworth expanded rapidly after independence as war refugees were joined by people who could not get accommodation in Harare [36]. Currently, the population of Epworth is estimated to be 161,840 [41]. The residents do not have access to most basic services such as access to clean water since Epworth is not under the administration of the City of Harare [36].

\section{Methodology}

The methodology used in this study comprised five major components, namely data acquisition, pre-processing, land use/cover classification, accuracy assessment and land use/cover change analysis. The following section gives details of the methodology used in this study.

\subsection{Data}

We acquired two Landsat 5 Thematic Mapper (TM) scenes, one Landsat Enhanced Thematic Mapper Plus $(\mathrm{ETM}+)$ scene and one Landsat 8 scene for land use/cover mapping (Table 1). Landsat 8 (originally called Landsat Data Continuity Mission) was launched on 11 February, 2013 as the eighth satellite in the Landsat program $[42,43]$. Landsat 8 consist of the Operational Land Imager (OLI) and the Thermal Infrared Sensor (TIRS) sensors, which provides images at a spatial resolution of 15 meters (panchromatic), 30 meters (visible, NIR, SWIR), and 100 meters (thermal) [42,43]. All Landsat image dates (1984, 2002, 2008 and 2013) were selected from cloud-free scenes acquired during the post-rainy season (winter and early summer). The selection of the Landsat image dates was based on the availability of corresponding reference data.The four Landsat scenes were geometrically corrected at the U.S. Geological Survey prior to downloading. Therefore, we resampled all Landsat scenes to $30 \mathrm{~m}$ for all bands (except the thermal and panchromatic) and georeferenced them to the Universal Transverse Mercator (UTM) map projection (zone 36 south). We did not perform atmospheric correction because the post-classification comparison approach adopted for land use/cover change analysis also compensates for variation in atmospheric conditions between dates since each land use/cover classification is performed independently $[2,44,45]$.

Reference datasets were developed for classifier training and classification accuracy assessment for each epoch (1984, 2002, 2008 and 2013). Black and white aerial photographs at a scale of 1:25,000 acquired in 1984 were used as reference data for the 1984 land use/cover classification. These aerial photographs were obtained from the Department of the Surveyor-General, Zimbabwe. Given the retrospective nature of our study and the unavailability of updated aerial photographs for 2002, reference data for 2002 was developed from a variety of sources. The primary reference data was obtained from the street map of Harare $(1: 30,000)$ that was published in 2001. However, the street map of Harare is highly generalized and thus difficult to collect non-built-up reference data such as vegetation and bareland/agriculture. Therefore, additional secondary reference data for 2002 was collected

Table 1. Summary of Landsat images used.

\begin{tabular}{ccc}
\hline Sensor & Date & Path/row \\
\hline Landsat5 TM & $22-06-1984$ & $170 / 072$ \\
Landsat7 ETM+ & $03-08-2002$ & $170 / 072$ \\
Landsat5 TM & $11-08-2008$ & $170 / 072$ \\
Landsat8 & $06-06-2013$ & $170 / 072$ \\
\hline
\end{tabular}


from high-resolution images (e.g., Quickbird image) in Google EarthTM (http://earth.google.com) as well as panchromatic OrbView-3 image (at $1 \mathrm{~m}$ spatial resolution) that were acquired on 5 October 2003. The street map was obtained from the Surveyor-General Zimbabwe, while OrbView-3 image was downloaded from the U.S. Geological Survey website. The primary reference data for 2008 was obtained from Global Positioning System (GPS) points collected during the August 2008 field survey. In addition, we used AVNIR-2 image with a spatial resolution of $10 \mathrm{~m}$ acquired on 12 May 2008 as secondary reference data sources. The AVNIR-2 sensor, which has a ground coverage (swath width) at nadir of $70 \mathrm{~km}$ collects data in three visible wavelengths $(0.42-0.50 \mu \mathrm{m}, 0.52-0.60 \mu \mathrm{m}$, and 0.61 - $0.69 \mu \mathrm{m})$, and one near infrared wavelength $(0.76$ $0.89 \mu \mathrm{m})$. Finally, primary reference data for 2013 was obtained from Global Positioning System (GPS) points collected in November 2012 as well as high-resolution images (acquired in 2013) from Google EarthTM.

\subsection{Land Use/Cover Classification}

An initial analysis of Landsat imagery and reference data (e.g., aerial photographs) revealed that the study area comprise a complex mosaic of urban, peri-urban, rural, vegetation and aquatic landscapes. Given the exploratory nature of the study and the focus on the expansion of built-up areas, we adopted three land use/cover classes (Table 2) based on the "Forestry Commission (Zimbabwe) and the Surveyor-General national cover classes" classification schemes as well as the author's a priori knowledge of the study area.

An initial supervised maximum likelihood classification revealed serious misclassification problems, particularly for the built-up areas and bareland/agriculture areas. In order to improve classification, we used support vector machines (SVMs) since previous studies demonstrated their effectiveness for mapping urban areas [34,46,47], especially in areas where training data is limited as is the case of Harare. Support vector machines (SVMs) are machine-learning algorithms based on statistical learning theory [48], which perform classification by constructing hyperplanes in a multidimensional space [28,29]. The SVM algorithms were introduced by Boser et al. [49] and Vapnik [50] to solve supervised classification and regression problems. In general, SVMs select the decision boundary from an infinite number of potential ones, leaving the greatest margin between the closest data points to the hyperplane, which are referred to as "support vectors" [30,32,35]. SVMs employ a kernel function to transform the training data into higher dimensional feature space for non-linear classification problems [32]. In this regard, SVMs are considered to be a kernel method since kernel functions are used to maximize the
Table 2. Land use/cover classification scheme.

\begin{tabular}{cc}
\hline Land use/cover & Description \\
\hline Built-up: & $\begin{array}{c}\text { Residential, commercial and services, industrial, } \\
\text { transportation, communication and utilities, } \\
\text { construction sites, and solid waste landfills. } \\
\text { All wooded areas, riverine vegetation, shrubs and } \\
\text { bushes, grass cover, golf courses, parks, cultivated } \\
\text { land or land being prepared for raising crops, } \\
\text { fallow, land under irrigation, bare exposed areas } \\
\text { and transitional areas. } \\
\text { Won-built-up: } \\
\text { Rivers and reservoirs. }\end{array}$ \\
\hline
\end{tabular}

margin between classes. Therefore, the SVMs have ability to delineate multi-modal classes in high dimensional feature spaces [51-54]. In this study, training and classification procedures using SVMs were performed in ENVI 4.8 [55]. First, SVMs were calibrated and finetuned by changing the kernel functions (types) and regularization (penalty) parameter. Following trial calibration, the radial basis function was selected for classification since it had the best accuracy. After classification, a postclassification analysis based on visual check was performed in ERDAS Imagine 2011 [56] to remove conspicuous misclassifications.

\subsection{Post-Classification Change Detection}

A post-classification change detection technique that cross-tabulates one land use/cover map from one date (1984) with another date (2002) was used to analyze land use/cover changes in ArcGIS 10.1 [57]. The pixel by pixel nature of this change allows the analysis of both quantity and spatial distribution of land use/cover changes. While the post-classification change detection technique is simple and straightforward, the land use/ cover change results are sensitive to inconsistencies in satellite image interpretation and misclassification errors [58]. This is because errors in individual land use/cover classification maps will also be present in the final land use/cover change map [58].

\section{Results and Discussion}

\subsection{Classification Accuracy Assessment}

In this study, we used reference pixels for accuracy assessment, which were independent from the training area pixels used for land use/cover classification. A total of 200 sample points were collected as reference data for each year (1984, 2002, 2008 and 2013) based on a random sampling approach. Four measures of accuracy assessment namely, the producer's accuracy (accounting for errors of omission), user's accuracy (accounting for errors of commission), overall accuracy and overall kappa were computed to evaluate classification accuracy. Overall land use/cover classification accuracy levels for 
the four dates ranged from $89 \%$ to $95 \%$ with an overall kappa that ranged from $86 \%$ to $93 \%$ (Tables 3(a) and (b)).

Generally, class-specific accuracies were high for nonbuilt-up areas, while class-specific accuracies for built-up areas ranged from moderate to high. The producer's accuracy for the built-up class ranged from $76.3 \%$ to $82.3 \%$, while the user's accuracy ranged from $80.3 \%$ to $96.7 \%$ over the study period (Tables 3(a) and (b)). The high user's accuracy and low producer's accuracy, particularly for the built-up class in 1984 indicate misclassification problems attributed to a number of factors. First, spectral confusion was observed between the built-up cover (that is, in newly developed high density residential areas) and the bareland/agriculture cover. This is because the two classes appear spectrally similar to the Landsat $5 \mathrm{TM}$ sensor given the low object-to-background contrast [21,59]. As a result, high density residential built-up areas were misclassified as bareland/agriculture areas or vice versa. Second, it was difficult to classify the built-up class in low density residential areas at the spatial resolution of the Landsat sensor. This is because most of the houses in the low density residential areas (to the north and north-east of the city center) are partially or totally obscured by trees. Consequently, the built-up class was underestimated, which also explains the lower producer's accuracy. While misclassifications were observed, our accuracy assessment results are relatively similar to those of Griffiths et al. [32], which indicates the effectiveness of SVMs for improving classification accuracy.

\subsection{Land Use/Cover Change Analysis}

Figure 2 shows maps depicting built-up and non-built-up classes for 1984, 2002, 2008 and 2013. Computed percentages of land use/cover classes show that in 1984, built-up and non-built-up areas occupied 12.6\% (118.6 $\left.\mathrm{km}^{2}\right)$ and $87.3 \%\left(822.9 \mathrm{~km}^{2}\right)$, respectively, while water areas occupied only $0.1 \%\left(0.7 \mathrm{~km}^{2}\right)$ of the study area. However, significant spatial expansion in built-up and subsequent decreases in non-built-up areas was observed in 2002. Built-up areas increased to $24.8 \%\left(233.9 \mathrm{~km}^{2}\right)$, while non-built-up areas decreased to $74.9 \%\left(705.6 \mathrm{~km}^{2}\right)$ of the study areas. A slight increase of $0.3 \%\left(3.2 \mathrm{~km}^{2}\right)$ in the spatial extent of water was also observed. Visual analysis of the 2008 land use/cover map revealed further increases in built-up areas, which occupied 32.1\% (302.7 $\mathrm{km}^{2}$ ), while non-built-up areas decreased to $67.5 \%$ $\left(636.1 \mathrm{~km}^{2}\right)$ of the study areas. Water areas changed slightly to $0.4 \%\left(3.5 \mathrm{~km}^{2}\right)$. For the 2013 land use/cover map, built-up and non-built-up areas occupied 36.3\% (342.2 $\left.\mathrm{km}^{2}\right)$ and $63.4 \%\left(597 \mathrm{~km}^{2}\right)$ of the study area. However, water areas occupied only $0.3 \%\left(3 \mathrm{~km}^{2}\right)$ of the study area. Generally, built-up areas increased substantially from 12.6\% to 36.3\% between 1984 and 2013 (Figure 2). Similar land use/cover changes have been observed in
Table 3. (a) Land use/cover classification accuracies (\%) for 1984 and 2002. (b) Land use/cover classification accuracies (\%) for 2008 and 2013.

(a)

\begin{tabular}{ccccc}
\hline Class & $\mathbf{1 9 8 4}$ & \multicolumn{3}{c}{$\mathbf{2 0 0 2}$} \\
\hline & Producer's & User's & Producer's & User's \\
Built-up & 77.8 & 80.3 & 78.1 & 91.9 \\
Non-built-up & 87.0 & 93.5 & 96.2 & 92.6 \\
Water & 100.0 & 80.6 & 100.0 & 96.7 \\
Overall accuracy & $\mathbf{8 9 . 0}$ & & $\mathbf{9 3 . 0}$ & \\
Overall kappa & $\mathbf{8 6 . 0}$ & & $\mathbf{9 1 . 0}$ & \\
\hline
\end{tabular}

(b)

\begin{tabular}{ccccc}
\hline Class & $\mathbf{2 0 0 8}$ & \multicolumn{3}{c}{$\mathbf{2 0 1 3}$} \\
\hline & Producer's & User's & Producer's & User's \\
Built-up & 82.3 & 96.7 & 76.3 & 96.7 \\
Non-built-up & 96.3 & 94.6 & 90.9 & 91.8 \\
Water & 100.0 & 93.3 & 100.0 & 100.0 \\
Overall accuracy & 95.0 & & 90.0 & \\
Overall kappa & 93.0 & & 86.0 & \\
\hline
\end{tabular}

other sub-Saharan African countries. For example, Mundia and Aniya [60] revealed that that the built-up areas expanded by $47 \mathrm{~km}^{2}$ in Nairobi (Kenya) between 1976 and 2000, while Forkuor and Cofie [61] observed that the built-up areas increased substantially in Freetown (Sierra Leone) between 1974 and 2000.

The rates of land use/cover changes varied during the 1984-2002, 2002-2008 and 2008-2013 time periods. Between 1984 and 2002, "non-built-up to built-up" change was approximately $114.4 \mathrm{~km}^{2}$ at annual rate of $6.4 \mathrm{~km}^{2}$. The majority of changes occurred in the northeastern, southwestern and western parts of the study area. Figure 3(a) shows the "non-built-up to built-up" change, which suggests dispersion of infill and extension developments, and urban sprawl in the form of leapfrog development in the study area. Infill development refers to growth of newly developed areas that are in the urbanized areas of the previous time period (that is, 1984), while extension refers to expansion of built-up areas within the urbanized areas [62]. Leapfrog development is defined as newly developed areas that are converted from non-developed parcels outside of and unconnected with existing urban built-up areas [62]. For example, the location of the new built-up areas particularly in northern and western parts of the study area indicates leapfrog developments (Figure 3(a)). However, an outward progression from the city center demonstrates infill and extension developments (Figure 3(a)). Analysis of the relationship between "non-built-up to built-up" changes (1984-2002) with distance to city center revealed that infill and extension developments occurred within all distance buffer zones (Figure 3(a)). On the other hand, leapfrog was obser- 


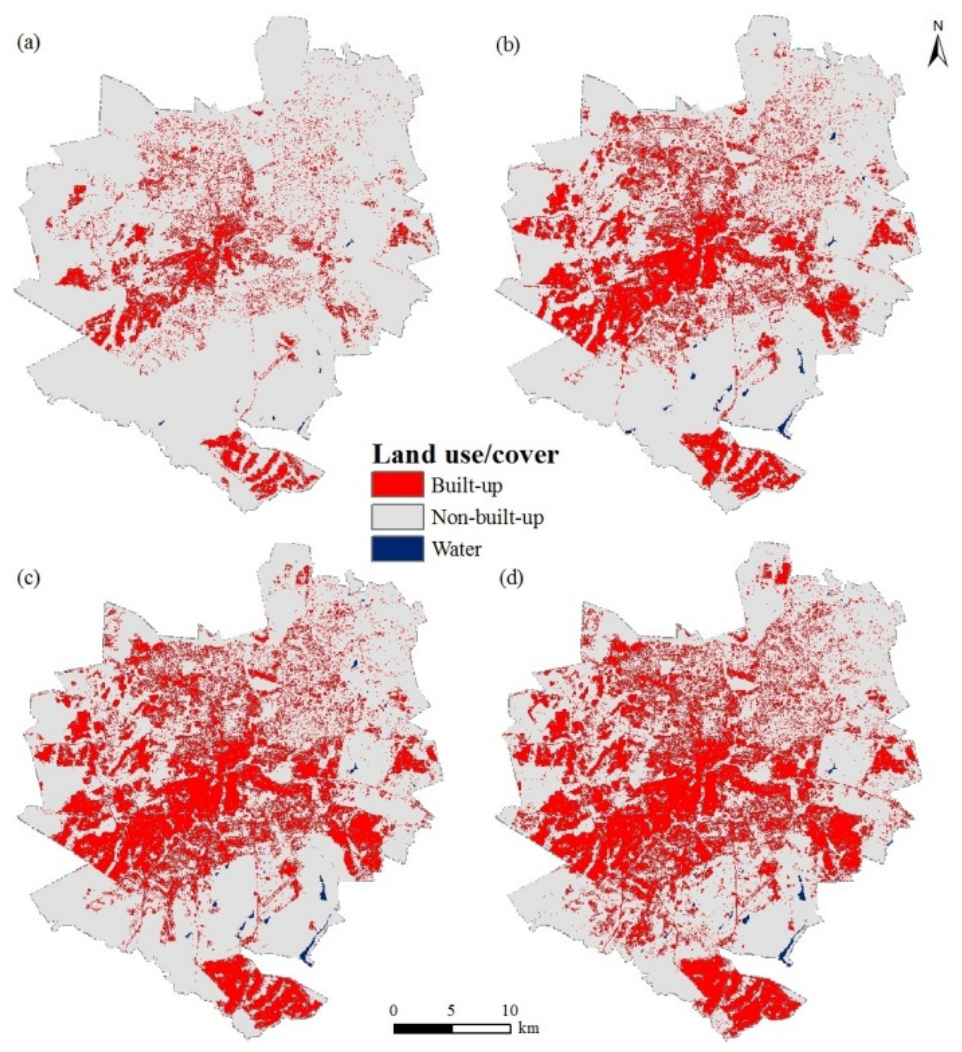

Figure 2. Land use/cover maps: (a) 1984, (b) 2002, (c) 2008 and (d) 2013.
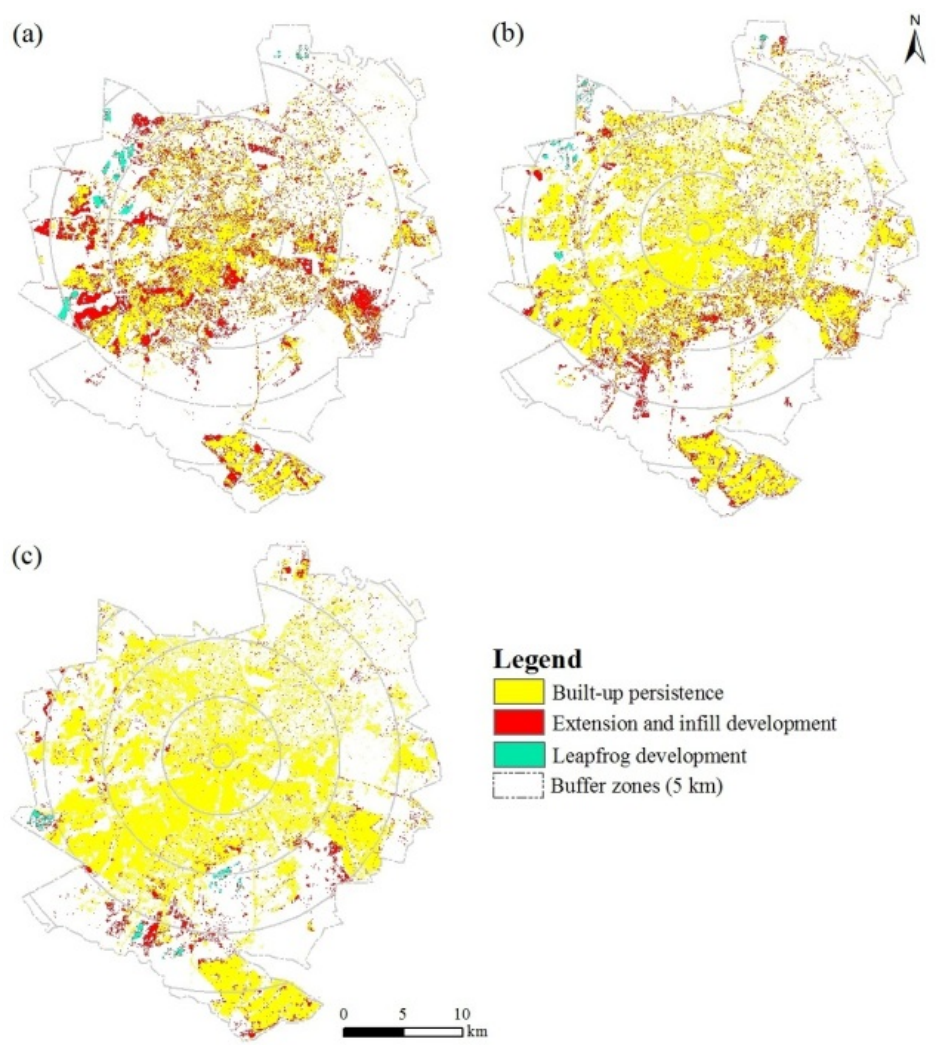

Figure 3. Extension, infill and leapfrog developments for (a) 1984-2002, (b) 2002-2008 and (c) 2002-2013. Note circles in light grey shows $5 \mathrm{~km}$ distance buffer zones. 
ved within 15-25 km distance buffer zones (Figure 3(a)).

During the "2002 to 2008 " period, there was a substantial increase in the "non-built-up to built-up" change (Figure 2(c)). As observed during the "19842002" period, urban growth between 2002 and 2008 is also characterized by leapfrog, extension and infill developments (Figure 3(b)). However, high urban growth is observed as shown by a high annual rate of "nonbuilt-up to built-up" changes (approximately $69.8 \mathrm{~km}^{2}$ at annual rate of $11.6 \mathrm{~km}^{2}$ ). Conspicuous "non-built-up to built-up" change patterns indicating extension and infill developments are observed in the study area. Nonetheless, the location of new built-up areas, particularly in the northern, western and north-western parts of the study area show leapfrog development (Figure 3(b)). Contrary to the 1984-2002 period, analysis of the relationship between "non-built-up to builtup" change (2002-2008) with distance to city center revealed that extension and infill developments were dominant within 15-25 km distance buffer zones (Figure 3(b)). However, leapfrog development was observed within the 20-25 km distance buffer zones (Figure 3(b)).

The "2008-2013" period revealed a slight decrease in "non-built-up to built-up" changes, which was approximately $37.5 \mathrm{~km}^{2}$ at annual rate of $7.5 \mathrm{~km}^{2}$. Figure 3(c) shows that urban growth between 2000 and 2013 was mainly characterized by extension and infill developments. However, patterns of leapfrog development are observed in the southern and south-western portions of the study area. The analysis of the relationship between "non-built-up to built-up" change (2002-2008) with distance to city center revealed that extension and fill developments occurred within 15 $25 \mathrm{~km}$ distance buffer zones, while leapfrog developments occurred within $20-25 \mathrm{~km}$ distance buffer zones (Figure 3(c)).

The land use/cover change analyses revealed significant rate of urban growth for the 1984-2002 and 2002-2008 time periods, while urban growth slowed down during the 2008-2013 period. While we did not carry out a quantitative analysis of the driving factors of urban growth, qualitative analysis based on literature review revealed that the rate of urban growth are attributed to a number of socioeconomic and policy factors during the post-independence period (that is, after 1980 when Zimbabwe got independent). According to the Central Statistical Office (CSO) [40] and ZimStats [41], population in Harare metropolitan province increased from approximately 830,000 in 1982 to $2,098,199$ inhabitants in 2012. This reflects an annual growth rate of $5.1 \%[10,40,41]$, which surpasses the average growth rate for Sub-Saharan Africa at 4.6\%.
Consequently, rapid population growth as a result of rural-urban migration increased the demand for housing and hence expansion in built-up areas $[10,63]$.

Taking into consideration rapid population growth and the need to improve the provision of housing in Harare, the government introduced housing development policies, which followed to a certain extent previous colonial government master plans [10]. The housing development policies and plans included infill housing development schemes given the growing concern about urban sprawl, high cost of service provisions and long commuting distances [36]. The infill housing development scheme focused more attention to the utilization of vacant land within existing high-income medium to low density residential areas [36]. Examples of the infill housing development schemes are located in the northwest and southern part of the city center [36]. On the other hand, the government continued with the development of low-income housing schemes in high density areas $[10,36]$. The lowincome high density development schemes focused on outward expansion because building costs were much lower in the outskirts of the city center (approximately 12 to $30 \mathrm{~km}$ ) than for infill housing developments $[36,63]$. Examples of low-income high density development schemes are located to north (e.g., Hatcliffe), east, southwest, and west of the city center as well as the continued expansion of Chitungwiza city in southeast part of the city center. To date, formal housing schemes initiated by resident cooperatives continue to develop built-up areas in Harare (urban and rural) and Chitungwiza districts. It is also important to note that Epworth, an informal settlement area to the southeast of the City of Harare also continued to expand.

\section{Conclusions}

The objective of this study was to map and analyze builtup and non-built-up cover in Harare metropolitan province. The classification results demonstrate that SVMs can be used to produce relatively accurate land use/cover maps from Landsat imagery. Based on the land use/cover maps for 1984, 2002, 2008 and 2013 along with change analyses, we found that significant urban growth occurred during the study period (1984-2002, 2002-2008 and 2008-2013). Our findings reveal that the urban growth process was dominated by infill, extension and leapfrog developments, which are attributed to rapid population growth and government housing policy among other factors.

While the SVMs classification approach improved the overall classification accuracy, the classification of the built-up class in low density residential areas still constitutes a major challenge. Thus, future work should continue to improve classification accuracy by incorporating 
multi-temporal images in the SVMs classification approach. Nonetheless, our results show that the SVMs classification approach present a cost-effective method for mapping urban land use/cover using medium-resolution satellite data such as Landsat. It is important to note that we conducted a rigorous accuracy assessment by using anniversary reference data for the 1984 and 2008 land use/cover maps, and near-anniversary reference data for the 2002 and 2013 land use/cover maps. Equally important, we employed the latest Landsat 8 image acquired in 2013 to highlight and update the current built-up and non-built-up areas in the study area. In light of the lack of spatial urban growth information in Harare metropolistan province, the land use/cover maps classified from the Landsat imagery can be used to provide a synoptic view of built-up and non-built-up areas. This could potentially assist decision-makers with information on the extent of built-up areas in order to guide the strategic implementation of sustainable urban land use planning in Harare metropolitan province. Last but not least, the SVMs approach facilitated a better understanding of land use/cover classification problems in the southern African urban setting, which can be applied to other metropolitan areas in Sub-Saharan Africa in particular, and other developing countries in general.

\section{Acknowledgements}

We thank Professor Masamu Aniya and JAXA for availing the reference ALOS AVNIR-2 image used in this study.

\section{REFERENCES}

[1] M. Pacione, "Sustainable Urban Development in the UK: Rhetoric or Reality?" Geography, Vol. 92, No. 3, 2007, p. 246-263. http://www.jstor.org/stable/40574338

[2] F. Yuan, K. E. Sawaya, B. C. Loeffelholz and M. E. Bauer, "Land Cover Classification and Change Analysis of the Twin Cities (Minnesota) Metropolitan Area by Multitemporal Landsat Remote Sensing," Remote Sensing of Environment, Vol. 98, No. 2-3, 2005, pp. 317-328. http://dx.doi.org/10.1016/j.rse.2005.08.006

[3] United Nations, "State of the World's Cities 2006/7," 2006.

http://www.unhabitat.org/content.asp?cid=3397\&catid=7 \& typeid $=46 \&$ subMenuId $=0$

[4] United Nations, "World Urbanization Prospects: The 2011 Revision,” 2012. http://esa.un.org/unpd/wup/index.htm

[5] I. Masser, "Managing Our Urban Future: The Role of Remote Sensing and Geographic Information Systems," Habitat International, Vol. 25, No. 4, 2001, pp. 503-512. http://dx.doi.org/10.1016/S0197-3975(01)00021-2

[6] H. Buhaug and H. Urdal, "An Urbanization Bomb? Population Growth and Social Disorder in Cities," Global Environmental Change, Vol. 23, No. 1, 2013, pp. 1-10. http://dx.doi.org/10.1016/j.gloenvcha.2012.10.016

[7] UN, "World Urbanization Prospects: The 2009 Revision," Highlights, United Nations Population Division, New York, 2010.

[8] UN-HABITAT, "The State of African Cities 2008-A Framework for Addressing Urban Challenges in Africa," UN-HABITAT, Nairobi, 2008.

[9] A. Brown, "Cities for the Urban Poor in Zimbabwe: Urban Space as a Resource for Sustainable Development," Development in Practice, Vol. 11, No. 2/3, 2001, pp. 263-281.

[10] C. Rakodi, "Harare-Inheriting a Settler-colonial City: Change or Continuity?" John Wiley \& Sons, Chichester, 1995.

[11] M. Herold, J. Scepan and K. C. Clarke, "The Use of Remote Sensing and Landscape Metrics to Describe Structures and Changes in Urban Land Uses," Environment and Planning A, Vol. 34, No. 8, 2002, pp. 1443-1458. http://dx.doi.org/10.1068/a3496

[12] M. W. Conitz, "GIS Applications in Africa: Introduction," Photogrammetric Engineering and Remote Sensing, Vol. 66, No. 6, 2000, pp. 672-673.

[13] X. Yang, "Parameterizing Support Vector Machines for Land Cover Classification," Photogrammetric Engineering and Remote Sensing, Vol. 77, No. 1, 2011, pp. 27-37. http://dx.doi.org/10.14358/PERS.77.1.27

[14] D. Ward, S. R. Phinn and A. T. Murray, "Monitoring Growth in Rapidly Urbanizing Areas Using Remotely Sensed Data," Professional Geographers, Vol. 52, No. 3, 2000, pp. 371-386. http://dx.doi.org/10.1111/0033-0124.00232

[15] B.Guindon, Y. Zhang and C. Dillabaugh, "Landsat Urban Mapping Based on a Combined Spectral-Spatial Methodology," Remote Sensing of Environment, Vol. 92, No. 2, 2004, pp. 218-232.

http://dx.doi.org/10.1016/j.rse.2004.06.015

[16] C. P. Lo and J. Choi, "A Hybrid Approach to Urban Land Use/Cover Mapping Using Landsat 7 Enhanced Thematic Mapper Plus (ETM+) Images," International Journal of Remote Sensing, Vol. 25, No. 14, 2004, pp. 2687-2700. http://dx.doi.org/10.1080/01431160310001618428

[17] D. Lu and Q. Weng, "A Survey of Image Classification Methods and Techniques for Improving Classification Performance," International Journal of Remote Sensing, Vol. 28, No. 5, 2007, pp. 823-870. http://dx.doi.org/10.1080/01431160600746456

[18] C. Small and J. Lu, "Estimation and Vicarious Validation of Urban Vegetation Abundance by Spectral Mixture Analysis," Remote Sensing of Environment, Vol. 100, No. 4, 2006, pp. 441-456. http://dx.doi.org/10.1016/j.rse.2005.10.023

[19] G. Xian and M. Crane, "Assessments of Urban Growth in the Tampa Bay Watershed Using Remote Sensing Data," Remote Sensing of Environment, Vol. 97, No. 2, 2005, pp. 203-215. http://dx.doi.org/10.1016/j.rse.2005.04.017

[20] P. Aplin and P. M. Atkinson, "Sub-Pixel Land Cover Mapping for Per-Field Classification," International Journal of Remote Sensing, Vol. 22, No. 14, 2001, pp. 2853- 
2858. http://dx.doi.org/10.1080/01431160110053176

[21] W. L. Stefanov, M. S. Ramsey and P. R. Christensen, "Monitoring Urban Land Cover Change: An Expert System Approach to Land Cover Classification of Semiarid to Arid Centers," Remote Sensing of Environment, Vol. 77, No. 2, 2001, pp. 173-185. http://dx.doi.org/10.1016/S0034-4257(01)00204-8

[22] P. M. Harris and S. J. Ventura, "The Integration of Geographic Data with Remotely Sensed Imagery to Improve Classification in Urban Area," Photogrammetric Engineering and Remote Sensing, Vol. 61, No. 8, 1995, pp. 993-998.

[23] P. Gong and P. J. Howarth, "The Use of Structural Information for Improving Land-Cover Classification Accuracies at the Rural-Urban Fringe," Photogrammetric Engineering and Remote Sensing, Vol. 56, No. 1, 1990, pp. 67-73.

[24] L. Moller-Jensen, "Knowledge-based Classification of an Urban Area Using Texture and Context Information in Landsat-TM imagery," Photogrammetric Engineering and Remote Sensing, Vol. 56, No. 6, 1990, pp. 899-904.

[25] H. Xu, "Extraction of Urban Built-up Land Features from Landsat Imagery Using a Thematic-Oriented Index Combination Technique," Photogrammetric Engineering and Remote Sensing, Vol. 73, No. 12, 2007, pp. 1381-1391.

[26] Y. Zha, J. Gao and S. Ni, "Use of Normalized Difference Built-Index in Automatically Mapping Urban Areas from TM Imagery," International Journal of Remote Sensing, Vol. 24, No. 3, 2003, pp. 583-594. http://dx.doi.org/10.1080/01431160304987

[27] K. C. Seto and W. Liu, "Comparing ARTMAP Neural Network with the Maximum-Likelihood Classifier for Detecting Urban Change," Photogrammetric Engineering and Remote Sensing, Vol. 69, No. 9, 2003, pp. 981-990.

[28] Z. Huang and B. G. Lee, "Combining Non-Parametric Models for Multisource Predictive Forest Mapping," Photogrammetric Engineering and Remote Sensing, Vol. 70, No. 4, 2004, 415-425.

[29] F. Melgani and L. Bruzzone, "Classification of Hyperspectral Remote Sensing Images with Support Vector Machines,"IEEE Transactions on Geoscience and Remote Sensing, Vol. 42, No. 8, 2004, pp. 1778-1990. http://dx.doi.org/10.1109/TGRS.2004.831865

[30] M. Pal and P. M. Mather, "Support Vector Machines for Classification in Remote Sensing," International Journal of Remote Sensing, Vol. 26, No. 5, 2005, pp. 1007-1011. http://dx.doi.org/10.1080/01431160512331314083

[31] R. G. Congalton and K. Green, "Assessing the Accuracy of Remotely Sensed Data: Principles and Practices," Lewis Publishers, New York, 1999.

[32] P. Griffiths, P. Hostert, O. Gruebner and S. Linden, "Mapping Megacity Growth with Multi-Sensor Data," Remote Sensing of Environment, Vol. 114, No. 2, 2010, pp. 426439. http://dx.doi.org/10.1016/j.rse.2009.09.012

[33] R. Gamanya, P. De Maeyer and M. De Dapper, "ObjectOriented Change Detection for the City of Harare, Zimbabwe," Expert Systems with Applications, Vol. 36, No. 1, 2009, pp. 571-588. http://dx.doi.org/10.1016/j.eswa.2007.09.067

[34] T. Esch, V. Himmler, G. Schorcht, M. Thiel, T. Wehrmann, F. Bachofer, C. Conrad, M. Schmidt and S. Dech, "Large-area Assessment of Impervious Surface Based on Integrated Analysis of Single-date Landsat-7 Images and Geospatial Vector Data," Remote Sensing of Environment, Vol. 113, No. 8, 2009, pp. 1678-1690. http://dx.doi.org/10.1016/j.rse.2009.03.012

[35] J. Knorn, A. Rabe, V. C. Radeloff, T. Kuemmerle, J. Kozak and P. Hostert, "Land Cover Mapping of Large Areas Using Chain Classification of Neighboring Landsat Satellite Images," Remote Sensing of Environment, Vol. 113, No. 5, 2009, pp. 957-964.

http://dx.doi.org/10.1016/j.rse.2009.01.010

[36] L. Zinyama, D. Tevera and S. Cumming, "Harare: The Growth and Problems of the City," University of Zimbabwe Publications, Harare, 1993.

[37] K. Nyamapfene, "Soils of Zimbabwe," Nehanda Publishers, Harare, 1991.

[38] S. Colquhoun, "Present Problems Facing the Harare City Council," In: L. Zinyama, D. Tevera and S. Cumming, Eds., Harare: The Growth and Problems of the City, University of Zimbabwe Publications, Harare, 1993, pp. 33-41.

[39] N. D. Mutizwa-Mangiza, "Urban Centres in Zimbabwe: Inter-censalChanges, 1962-1982," Geography, Vol. 71, No. 2, 1986, pp. 148-151. http://www.jstor.org/stable/40571088

[40] CSO (Central Statistical Office), "Census 2002 Population Census: Provincial Profile Harare," CSO (Central Statistical Office), Harare, 2004.

[41] ZimStats (Zimbabwe National Statistics Agency), "Census 2012: Preliminary Report," ZimStats (Zimbabwe National Statistics Agency), Harare, 2012.

[42] NASA, "Landsat 8 Overview, 2013,” 2013. http://www.nasa.gov/mission_pages/landsat/overview/ind ex.html, 2013.

[43] USGS, "Landsat 8 Data Product Information," 2013. http://landsat.usgs.gov/LDCM_DataProduct.php, 2013.

[44] P. Coppin, I. Jonckheere, K. Nackaerts, B. Muys and E. Lambin, "Digital Change Detection Methods in Ecosystem Monitoring: A Review," International Journal of Remote Sensing, Vol. 25, No. 9, 2004, pp. 1565-1596. http://dx.doi.org/10.1080/0143116031000101675

[45] C. Song, C. E. Woodcock, K. C. Seto, M. P. Lenney and S. A. Macomber, "Classification and Change Detection Using Landsat TM Data: When and How to Correct Atmospheric Effects?'Remote Sensing of Environment, Vol. 75, No. 2, 2001, pp. 230-244. http://dx.doi.org/10.1016/S0034-4257(00)00169-3

[46] H. Nemmour and Y. Chibani, "Multiple Support Vector Machines for Land Cover Change Detection: An Application for Mapping Urban Extensions," ISPRS Journal of Photogrammetry and Remote Sensing, Vol. 61, No. 2, 2006, pp. 125-133. http://dx.doi.org/10.1016/j.isprsjprs.2006.09.004

[47] P. Watanachaturaporn, M. K. Arora and P. K. Varshney, "Multisource Classification Using Support Vector Ma- 
chines: An Empirical Comparison with Decision Tree and Neural Network Classifiers," Photogrammetric Engineering and Remote Sensing, Vol. 74, No. 2, 2008, pp. 239246.

[48] C. Cortes and V. Vapnik, "Support-Vector Network," Machine Learning, Vol. 20, No. 3, 1995, pp. 273-297. http://dx.doi.org/10.1007/BF00994018

[49] B. E. Boser, I. M. Guyon and V. N. Vapnik, "A Training Algorithm for Optimal Margin Classifiers," Proceedings of the Fifth Annual Workshop on Computational Learning Theory, ACM, New York, 1992, pp. 144-152. http://dx.doi.org/10.1145/130385.130401

[50] V. N. Vapnik, "The Nature of Statistical Learning Theory," John Wiley \& Sons, New York, 1998.

[51] R. Zhang and J. Ma, "An Improved SVM Method P-SVM for Classification of Remotely Sensed Data," International Journal of Remote Sensing, Vol. 29, No. 20, 2008, pp. 6029-6036. http://dx.doi.org/10.1080/01431160802220151

[52] B. Dixon and N. Candade, "Multispectral Landuse Classification Using Neural Networks and Support Vector Machines: One or the Other, or Both?" International Journal of Remote Sensing, Vol. 29, No. 4, 2008, pp. 1185-1206. http://dx.doi.org/10.1080/01431160701294661

[53] X. Cao, J. Chen, H. Imura and O. Higashi, "A SVM-Based Method to Extract Urban Areas from DMSP-OLS and SPOT VGT Data," Remote Sensing of Environment, Vol. 113, No. 10, 2009, pp. 2205-2209. http://dx.doi.org/10.1016/j.rse.2009.06.001

[54] X. F. Song, Z. Duan and X. G. Jiang, "Comparison of Artificial Neural Networks and Support Vector Machine Classifiers for Land Cover Classification in Northern China Using a SPOT-5 HRG Image," International
Journal of Remote Sensing, Vol. 33, No. 10, 2012, pp. 3301-3320.

http://dx.doi.org/10.1080/01431161.2011.568531

[55] ITT-Visual Information Solutions, "ENVI 4.8 Help," Boulder, 2010.

[56] Intergraph Corporation, "ERDAS Field Guide 2011," ERDAS Inc, Norcross, 2011.

[57] ESRI, “ArcGIS Version 10.1,” ESRI Inc, Redlands, 2012.

[58] A. Singh, "Digital Change Detection Techniques Using Remotely Sensed Data," International Journal of Remote Sensing, Vol. 10, No. 6, 1989, pp. 989-1003. http://dx.doi.org/10.1080/01431168908903939

[59] J. R. Jensen, "Remote Sensing of the Environment: An Earth Resource Perspective," Prentice-Hall, Upper Saddle River, 2000.

[60] C. N. Mundia and M. Aniya, "Analysis of Land Use/Cover Changes and Urban Expansion of Nairobi City Using Remote Sensing and GIS," International Journal of Remote Sensing, Vol. 26, No. 13, 2005, pp. 2831-2849. http://dx.doi.org/10.1080/01431160500117865

[61] G. Forkuor and O. Cofie, "Dynamics of Land-Use and Land-Cover Change in Freetown, Sierra Leone and Its Effects on Urban and Peri-Urban Agriculture-A Remote Sensing Approach," International Journal of Remote Sensing, Vol. 32, No. 4, 2011, pp. 1017-1037. http://dx.doi.org/10.1080/01431160903505302

[62] W. Yue, Y. Liu and P. Fan, "Measuring Urban Sprawl and Its Drivers in Large Chinese Cities: The Case of Hangzhou," Land Use Policy, Vol. 31, 2013, pp. 358-370. http://dx.doi.org/10.1016/j.landusepol.2012.07.018

[63] Ministry of Economic Planning \& Investment Promotion (MEPIP), "Zimbabwe-Medium Term Plan 2011-2015," Republic of Zimbabwe, Harare, 2011. 